\title{
The Metabolism of Propionate in the Colourless Alga, Prototheca zopfii
}

\author{
By A. G. CALLELY AND D. LLOYD \\ Department of Botany (Microbiology Section), University College, Cathays Park, Cardiff
}

(Received 18 December 1963)

Propionate is an adequate source of carbon and energy for the growth of the colourless obligatoryheterotrophic alga, Prototheca zopfii (Barker, 1935). The yeast autolysate in the media used by Barker (1935) can be replaced by thiamine (Anderson, 1945), this being the only preformed vitamin that this organism requires.

A number of different pathways of propionate metabolism have been reported which lead to the production of compounds which could be further metabolized via the tricarboxylic acid cycle:

(1) The succinate pathway. Evidence at the enzyme level indicates that this is the principal pathway by which propionate is oxidized by mammalian tissues; it involves the activation of propionate and the subsequent carboxylation of propionyl-CoA to yield methylmalonyl-CoA (Lardy \& Peanasky, 1953; Flavin, Ortiz \& Ochoa, 1955; Katz \& Chaikoff, 1955; Flavin, Castro-Mendoza \& Beck, $1956 a$; Flavin, Castro-Mendoza \& Ochoa, $1956 b$; Friedberg, Adler \& Lardy, 1956; Lardy \& Adler, 1956). Methylmalonyl-CoA is isomerized to give succinyl-CoA (Flavin et al. 1956a; Beck \& Ochoa, 1958); it has been shown with, for example, cell-free preparations from Propionibacterium (Stadtman, Overath, Eggerer \& Lynen, 1960), from rat-liver (Gurnani, Mistry \& Johnson, 1960) and from sheep-kidney (Lengyel, Mazumder \& Ochoa, 1960) that the coenzyme form of vitamin $B_{12}$ is required as a cofactor in this reaction. This same vitamin $B_{12}$-dependent reaction has also been demonstrated in the flagellate Ochromonas malhamensis when grown on propionate (Arnstein \& White, 1962).

(2) The acrylate pathway. This involves the direct oxidation of propionate via acrylate to lactate and thence to pyruvate (Mahler \& Huennekens, 1953).

(3) The malonic semialdehyde pathway originally proposed by Rendina \& Coon (1957). In this case propionate, after activation, is converted into malonic semialdehyde via acrylyl-CoA, $\beta$-hydroxypropionyl-CoA and free $\beta$-hydroxypropionate. Giovanelli \& Stumpf (1958) have shown in plant tissues that the malonic semialdehyde is further oxidized to acetyl-CoA and carbon dioxide.

(4) The malonyl-semialdehyde-CoA pathway.
Like pathway (3) above, propionate is first converted into $\beta$-hydroxypropionyl-CoA; this is then oxidized to malonyl-semialdehyde-CoA and thence to malonyl-CoA, from which an acetyl unit would be formed. This sequence has been demonstrated in a system purified from Clostridium kluyveri (Vagelos, 1960). Here the acetyl unit would be derived from C-1 and C-2 of propionate, whereas in the malonic semialdehyde pathway C-3 and C-2 of propionate become respectively $\mathrm{C}-1$ and $\mathrm{C}-2$ of acetate.

(5) The $\alpha$-hydroxyglutarate pathway. Here propionate, after activation, condenses with glyoxylate to yield $\alpha$-hydroxyglutarate; this compound is then cleaved to produce acetate and lactate, the latter, presumably, being converted into pyruvate. It has been suggested that these reactions play a role in the growth of Escherichia coli adapted to use propionate as sole source of carbon (Reeves \& Ajl, 1963). The glyoxylate required for the first reaction would be derived from isocitrate, this particular step being catalysed by isocitrate lyase.

Previous studies with Prototheca zopfii (Callely \& Lloyd, 1964) have shown that the tricarboxylic acid cycle is a major metabolic pathway in this organism. The present investigation was undertaken to try to elucidate the pathway by which propionate enters the tricarboxylic acid cycle and also its conversion into intermediary metabolites essential for the synthesis of cellular components during growth.

\section{MATERIALS AND METHODS}

Maintenance and growth of the organism. The organism was the same as that used by Callely \& Lloyd (1964); it was grown and maintained as previously described except that $0.02 \mathrm{M}$-sodium propionate replaced acetate in the growth medium.

Preparation of cell extracts. French-press extracts were

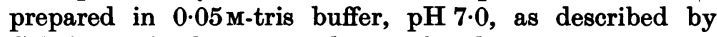
Callely \& Lloyd (1964) and centrifuged at $4^{\circ}$ for $3 \mathrm{~min}$. at $1000 \mathrm{~g}$ to remove remaining intact cells. Except where stated they were not further fractionated.

Radioactive materials. All radioactive chemicals were obtained from The Radiochemical Centre, Amersham, Bucks. They were purified, immediately before use, by partition chromatography on ether-washed Celite 535 (Johns-Manville Co. Ltd., London, S.W. 1) by the method 
of Swim \& Krampitz (1954). The contents of the phials containing the radioactive compounds were dissolved in $0.5 \mathrm{ml}$. of water; this solution was acidified to a $\mathrm{pH}$ less than 2.0 with the minimal amount of $3 \mathrm{~N}-\mathrm{H}_{2} \mathrm{SO}_{4}$ and then applied to the top of the column. The appropriate eluent fractions were shaken with three changes of $0.01 \mathrm{~N}-\mathrm{NaOH}$ $(0.2 \mathrm{vol}$.); the three alkaline washes were pooled, evaporated gently to small bulk, cooled and neutralized with $0 \cdot 1 \mathrm{~N}-\mathrm{H}_{2} \mathrm{SO}_{4}$.

Other materials. GSH, 2,6-dichlorophenol-indophenol, $\beta$-propionolactone and DL-isocitric acid lactone were all obtained from L. Light and Co. Ltd., Colnbrook, Bucks., ATP was from Sigma Chemical Co., St Louis, Mo., U.S.A., and CoA was from C. F. Boehringer und Soehne G.m.b.H., Mannheim, Germany. All other chemicals were of the highest purity commercially available.

Acetyl-CoA and propionyl-CoA were synthesized from the corresponding acid anhydrides (Stadtman, 1957); acrylyl-CoA and $\beta$-hydroxypropionyl-CoA were prepared by the mixed anhydride method (Stadtman, 1957).

Sodium DL-isocitrate was prepared from the lactone (Deutsch \& Phillips, 1957). Sodium glyoxylate was prepared from tartaric acid by periodate oxidation (Radin, Metzler, Bloom \& Westerfield, 1955); $\beta$-hydroxypropionate was prepared from $\beta$-propiolactone by the method described by Robinson \& Coon (1963). Malonic semialdehyde was generated, as required, from the ester acetal (generously provided by Professor M. J. Coon) as described by Robinson \& Coon (1963).

Chromatographic analysis and radioautography. Experiments in which radioactive substrates were incubated with extracts (total vol. $1.0 \mathrm{ml}$.) were terminated by the addition of $1.0 \mathrm{ml}$. of boiling methanol. The precipitate was removed by centrifuging, the supernatant being kept; the precipitate was washed once with $1.0 \mathrm{ml}$. of aq. $20 \%(\mathrm{v} / \mathrm{v})$ methanol. The original supernatant and washing were combined and evaporated to dryness at $60^{\circ}$; the solid material obtained was dissolved in $0.1 \mathrm{ml}$. of aq. $20 \%$ $(\mathrm{v} / \mathrm{v})$ methanol. Samples $(0.05 \mathrm{ml}$.) of such solutions were applied to the origin positions of paper chromatograms; the papers (Whatman no. 4; 18 in. $\times 18$ in.) were developed two-dimensionally in the descending direction with the solvent systems used by Kornberg (1958).

Radioautographs were made by applying Kodirex X-ray film (Kodak Ltd.) to the developed chromatograms for 14-21 days. The radioactive areas located on the paper were assayed for their activity directly with a mica-endwindow Geiger-Müller counter tube (General Electric Co., type 2 B 2) used in conjunction with automatic counting equipment (type AC 300/6; Panax Equipment Ltd., Redhill, Surrey). Each area was counted for 4000 counts and corrected for background radioactivity.

The radioactive compounds detected were eluted from the chromatograms with water and subjected to cochromatography with authentic markers of the suspected substances. Exact coincidence, in several solvent systems, of the resulting radioactive spot and the area located by spraying with a suitable reagent was taken as evidence of identification. The solvent systems were those used by Kornberg (1958).

Carboxylic acids were detected on chromatograms by spraying with ethanolic $0.04 \%(w / v)$ bromophenol blue, adjusted to $\mathrm{pH} 8$ with $\mathrm{NaOH}$; amino acids were detected with $0.2 \%(\mathrm{w} / \mathrm{v})$ ninhydrin in acetone.
Other analytical methods. Oxygen uptake and $\mathrm{CO}_{2}$ output were made in conventional Warburg apparatus (Umbreit, Burris \& Stauffer, 1957).

Oxo acids were detected by the method of Friedemann \& Haugen (1943), except that the temperature of the various solutions was never allowed to rise above $4^{\circ}$. The resultant 2,4-dinitrophenylhydrazones were chromatographed on paper one-dimensionally in the descending direction with the solvent system of Den, Robinson \& Coon (1959). Malonic semialdehyde was estimated by a method sug. gested by Professor M. J. Coon (personal communication) which is based on a procedure described by Kalnitsky \& Tapley (1958).

Protein was estimated by the method of Warburg \& Christian (1941).

Thiol groups were assayed for by the method of Grunert \& Phillips (1951).

Determination of enzyme activities. The propionateactivating enzyme was determined as described by Jones \& Lipmann (1955) for the corresponding acetate-activating system. Acetylhydroxamate was used as an arbitrary standard in all hydroxamate determinations.

Malonic semialdehyde oxidative decarboxylase was assayed according to the procedure used by Yamada \& Jakoby (1960).

Malate synthase and isocitrate lyase were assayed spectrophotometrically (Dixon \& Kornberg, 1959). The malatesynthase assay was done in a Cary recording spectrophotometer. Other spectrophotometric assays were done at room temperature in a Unicam SP. 500 spectrophotometer with cells of $1 \mathrm{~cm}$. light-path.

\section{RESULTS}

\section{Experiments with whole cells}

Washed non-proliferating suspensions of propionate-grown cells readily oxidized propionate. The oxygen uptake with propionate ( $1.65 \mathrm{~mm})$ was decreased by $43 \%$ by $0.1 \mathrm{~mm}$-sodium arsenite and depressed below the endogenous level by $1 \mathrm{~mm}$ arsenite (Fig. 1).

Oxo acids were detected in reaction mixtures at the end of these arsenite inhibition experiments. Chromatography of their 2,4-dinitrophenylhydrazones indicated that one of the two oxo acids detected was $\alpha$-oxoglutaric acid; the second acid was tentatively identified as malonic semialdehyde, as its 2,4-dinitrophenylhydrazone ran similarly to an authentic specimen of the same malonic semialdehyde derivative.

If the above procedure was carried out at $30^{\circ}$ $\alpha$-oxoglutaric acid could still be detected, but the other oxo acid derivative was either present in much smaller amounts or entirely absent. In its place another 2,4-dinitrophenylhydrazone was produced which ran identically with an authentic specimen of acetaldehyde 2,4-dinitrophenylhydrazone.

This supports the view that malonic semialdehyde accumulates when cells metabolizing pro- 
pionate are poisoned with arsenite, as malonic semialdehyde is an unstable compound (Den et al. 1959) and readily decomposes to give carbon dioxide and acetaldehyde.

To ensure that these compounds were not being produced from endogenous substrates, washed cells from a $500 \mathrm{ml}$. culture were resuspended in $25 \mathrm{ml}$. of $0.015 \mathrm{M}$-phosphate buffer, $\mathrm{pH} 7 \cdot 0$, containing propionate $(20 \mu$ moles $)$ and sodium arsenite $(25 \mu$ moles). When this mixture was at $30^{\circ}, 10 \mu \mathrm{C}$ of $\left[1{ }^{14} \mathrm{C}\right]$ propionate was added. After $30 \mathrm{~min}$. the mixture was rapidly cooled to about $4^{\circ}$ and any oxo acids present were isolated as their 2,4-dinitrophenylhydrazones. A portion of the isolated derivatives was chromatographed; after development, the air-dried chromatogram was subjected to radioautography. The experiment was repeated with $\left[2-{ }^{14} \mathrm{C}\right]$ propionate instead of $\left[1-{ }^{14} \mathrm{C}\right]$ propionate.

In both cases two labelled oxo acids were detected; their position as revealed on film by radioautography corresponded exactly to the yellow 2,4-dinitrophenylhydrazones of $\alpha$-oxoglutaric acid and malonic semialdehyde visible on the paper chromatograms. From $\left[1{ }^{14} \mathrm{C}\right]$ propionate $85 \%$ of the total activity detected was confined to the malonic semialdehyde, the remaining $15 \%$ being present in the $\alpha$-oxoglutaric acid; from $\left[2-{ }^{14} \mathrm{C}\right]$ propionate the corresponding values were 42 and $58 \%$ respectively. This could indicate that C-2 of

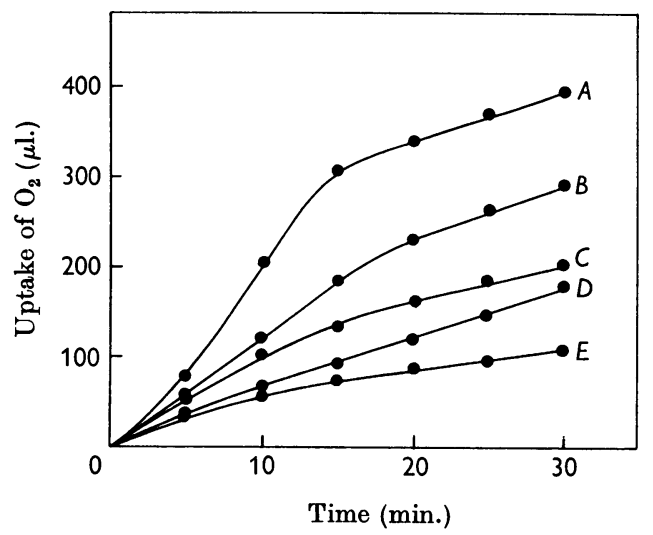

Fig. 1. Oxidation of propionate by washed suspensions of propionate-grown cells in the presence of arsenite. Each flask contained $700 \mu$ moles of $\mathrm{KOH}$ in the centre well, $0.015 \mathrm{M}$-phosphate buffer, $\mathrm{pH} 7 \cdot 2$, and propionate and arsenite (as indicated) in the main compartment, and $1 \mathrm{ml}$. of algal suspension ( $22 \mathrm{mg}$. dry wt. of cells) in the side bulb; the total volume of reactants was $3 \mathrm{ml}$. Each flask except $C$ contained $5 \mu$ moles of propionate and: $A$, no arsenite; $B, 0.3 \mu$ mole of arsenite; $C$, no arsenite (endogenous); $D, 3 \mu$ moles of arsenite; $E, 30 \mu$ moles of arsenite. Incubation was in air at $30^{\circ}$; cell suspension were added at zero time. propionate is more readily incorporated than C-1 into $\alpha$-oxoglutaric acid.

\section{Experiments with cell-free extracts}

When $1 \mu \mathrm{C}$ of $\left[1-{ }^{14} \mathrm{C}\right]$ propionate was incubated for $15 \mathrm{~min}$. at $30^{\circ}$, with $0.1 \mathrm{ml}$. of a French-press extract ( $3 \mathrm{mg}$. of protein) and CoA $(0 \cdot 1 \mu \mathrm{mole})$, ATP ( $1 \mu \mathrm{mole})$, magnesium chloride $(1 \mu \mathrm{mole})$ and $\mathrm{NAD}^{+}(1 \mu \mathrm{mole})$, only one labelled non-volatile methanol-soluble metabolite was detected by radioautography. Co-chromatography of this compound in a variety of solvents showed that it was $\beta$-hydroxypropionate.

The radioautographs obtained in analogous experiments with $\left[2{ }^{14} \mathrm{C}\right]$ propionate instead of $\left[1-{ }^{14} \mathrm{C}\right]$ propionate were more complex, activity being found in $\beta$-hydroxypropionate, aspartate, glutamate, citrate, malate and an as yet unidentified compound, designated $\mathrm{X}$.

When extracts fortified as above metabolized $\left[2-{ }^{14} \mathrm{C}\right]$ propionate plus glyoxylate $(1 \mu \mathrm{mole})$ or DLisocitrate $(2 \mu$ moles $)$ or oxaloacetate $(1 \mu \mathrm{mole})$, the results were comparable with those obtained in similar experiments where $\left[2{ }^{14} \mathrm{C}\right]$ acetate replaced $\left[2-{ }^{14} \mathrm{C}\right]$ propionate. The addition of oxaloacetate raises the proportion of label incorporated into citrate and lowers that incorporated into malate, as compared with the values obtained in experiments without oxaloacetate; the addition of glyoxylate or isocitrate increases the percentage incorporation of label into malate while depressing that into the citrate (Table 1).

In all cases $75-85 \%$ of the total activity from $\left[2-{ }^{14} \mathrm{C}\right]$ propionate is in the two compounds, $\beta$ hydroxypropionate and $X$, which never appear on chromatograms obtained in the experiments where $\left[2-{ }^{14} \mathrm{C}\right]$ acetate is used instead of $\left[2{ }^{14} \mathrm{C}\right]$ propionate.

The above results are consistent with the operation of the malonic semialdehyde pathway. The presence of the various enzymes of this pathway in cell-free extracts of propionate-grown cells was demonstrated by the following experiments.

Activation of propionate. On incubating unfractionated extracts with propionate and CoA in the presence of ATP, GSH and $\mathrm{Mg}^{2+}$ ions, a compound, presumably propionyl-CoA, that gave a positive hydroxamate reaction, was formed (Lipmann \& Tuttle, 1945; Fig. 2).

Propionyl-coenzyme A dehydrogenase. Incubation of an unfractionated extract with 2,6-dichlorophenol-indophenol at $\mathrm{pH} 7 \cdot 0$ resulted in the reduction of the latter compound on the addition of propionyl-CoA and the production of, presumably, acrylyl-CoA (Fig. 3).

Hydration of acrylyl-coenzyme $A$. This compound was rapidly metabolized on the addition of a crude cell-free extract, the reaction being followed spectrophotometrically at $295 \mathrm{~m} \mu$ (Stadtman, 1955; 
Table 1. Percentage incorporation of $\left[2-{ }^{14} \mathrm{C}\right]$ acetate and $\left[2-{ }^{14} \mathrm{C}\right]$ propionate into malate and citrate by fortified cell-free extracts of propionate-grown cells

The complete systems contained, in $1 \mathrm{ml}$.: extract ( $3 \mathrm{mg}$. of protein), $\mathrm{CoA}(0 \cdot 1 \mu \mathrm{mole}), \mathrm{ATP}(1 \mu \mathrm{mole}), \mathrm{MgCl}_{2}$ $(1 \mu \mathrm{mole}), \mathrm{NAD}+(1 \mu \mathrm{mole})$ and either (Expt. A) $\left[2-{ }^{14} \mathrm{C}\right]$ acetate $(0 \cdot 1 \mu$ mole; $1 \mu \mathrm{C})$ or (Expt. B) $\left[2-{ }^{14} \mathrm{C}\right]$ propionate $(0.04 \mu \mathrm{mole} ; 1 \mu \mathrm{c})$; other unlabelled intermediates are indicated below. After $15 \mathrm{~min}$. at $30^{\circ}, 1 \mathrm{ml}$. of boiling methanol was added. Each sample was separately treated for chromatography and radioautography as described in the text. The activity of each labelled compound detected was measured and the total activity on each chromatogram calculated.

$\begin{array}{cc}\text { Expt. } & \text { Sample } \\ \text { no. } & \text { no. } \\ \text { A } & 1 \\ & 2 \\ & 3 \\ & 4 \\ \text { B } & 1 \\ & 2 \\ & 3 \\ & 4\end{array}$

\section{Compound added}

None

Oxaloacetate ( $1 \mu$ mole)

Glyoxylate $(1 \mu$ mole $)$

Isocitrate ( $2 \mu \mathrm{moles})$

None

Oxaloacetate ( $1 \mu \mathrm{mole})$

Glyoxylate ( $1 \mu \mathrm{mole})$

Isocitrate (2 $\mu \mathrm{moles})$
Percentage of total activity

\begin{tabular}{cc}
\hline In malate & In citrate \\
8.2 & $82 \cdot 3$ \\
0.7 & 84.8 \\
$56 \cdot 4$ & $8 \cdot 9$ \\
$53 \cdot 0$ & $29 \cdot 6$ \\
$1 \cdot 0$ & $4 \cdot 3$ \\
Not detected & $9 \cdot 5$ \\
$9 \cdot 2$ & 0.9 \\
3.9 & 2.9
\end{tabular}

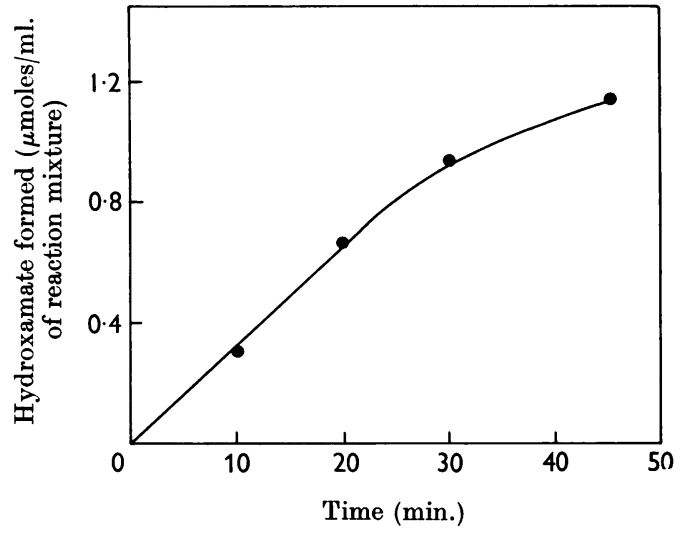

Fig. 2. Activation of propionate by unfractionated extracts. The reaction mixture (total vol. $4 \cdot 2 \mathrm{ml}$.) contained ( $\mu$ moles) : sodium propionate, $40 ; 0.015 \mathrm{M}$-phosphate buffer, pH 7.2, 400; ATP, 40; CoA, 0.32; GSH, 40; $\mathrm{MgSO}_{4}, 40$; NaF, 200; freshly neutralized hydroxylamine, 800 . The reaction was started by the addition of extract $(15.9 \mathrm{mg}$. of protein). The incubation temperature was $30^{\circ}$. Samples were taken at intervals and the colour produced, on the addition of the $\mathrm{FeCl}_{3}$ reagent, was recorded at $540 \mathrm{~m} \mu$ against blanks treated in the same way taken from a reaction mixture identical with the above but lacking CoA.

Fig. 4). There was no reaction when a boiled extract was used as the enzyme preparation.

No added cofactors were necessary for the reaction to take place, nor was the reaction rate altered in the presence of an excess of $\mathrm{NH}_{4}^{+}$ions ( $25 \mu$ moles of ammonium chloride); thus it would appear that neither the addition of hydrogen nor amination is taking place and that the reaction observed is the addition of the elements of water

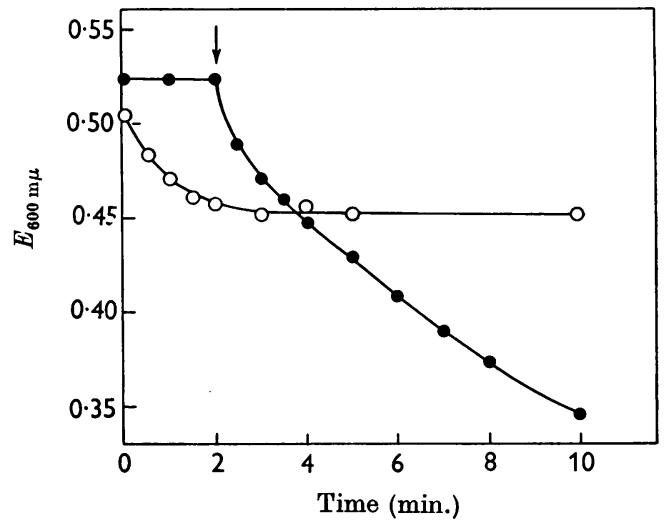

Fig. 3. Propionyl-CoA-dehydrogenase activity in unfractionated extracts. Reaction mixtures (total volume $3 \mathrm{ml}$.) contained: $30 \mu$ moles of tris buffer, $\mathrm{pH} 7 \cdot 0 ; 0.15 \mathrm{ml}$. of $0.05 \% 2,6$-dichlorophenol-indophenol; approx. $0.33 \mu$ mole of propionyl-CoA either present (O) or absent (O); extract (1.3 mg. of protein). The reaction was started by adding extract at the time indicated by the arrow. $O$, The extract was added at zero time. The extinction at $600 \mathrm{~m} \mu$ was measured at room temperature against a control cell lacking 2,6-dichlorophenol-indopheno] only.

across the double bond of the acrylyl moiety producing, presumably, $\beta$-hydroxypropionyl-CoA.

Deacylation of $\beta$-hydroxypropionyl-coenzyme $A$. Incubation of this substrate with extracts at $\mathrm{pH} 5.6$ resulted in the formation of free $\mathrm{SH}$ groups and the disappearance of acyl-CoA, though the theoretical 1:1 stoicheiometry has never been obtained. This reaction did not occur if a boiled extract was used instead of active enzyme, nor could free SH groups or acyl-CoA be detected in 
control experiments where the substrate was omitted.

Similar results were obtained when acrylyl-CoA was used as the substrate.

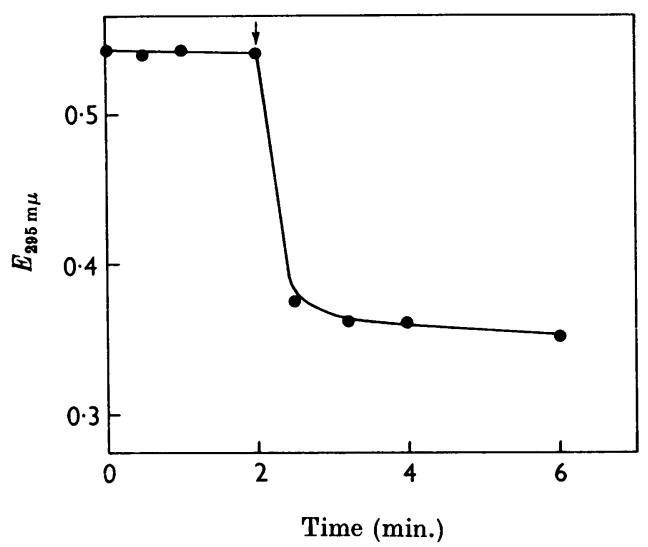

Fig. 4. Hydration of acrylyl-CoA by unfractionated extracts. The reaction mixture (total vol. $0.44 \mathrm{ml}$.) contained approx. $0.15 \mu$ mole of acrylyl-CoA and $0.015 \mathrm{M}$-phosphate buffer, $\mathrm{pH} 7 \cdot 0$. The reaction was started by the addition of extract $(0.01 \mathrm{ml}, 0.11 \mathrm{mg}$. of protein) at the time indicated by the arrow, and followed at room temperature by measuring the extinction at $295 \mathrm{~m} \mu$ against a control cell containing buffer and extract only.

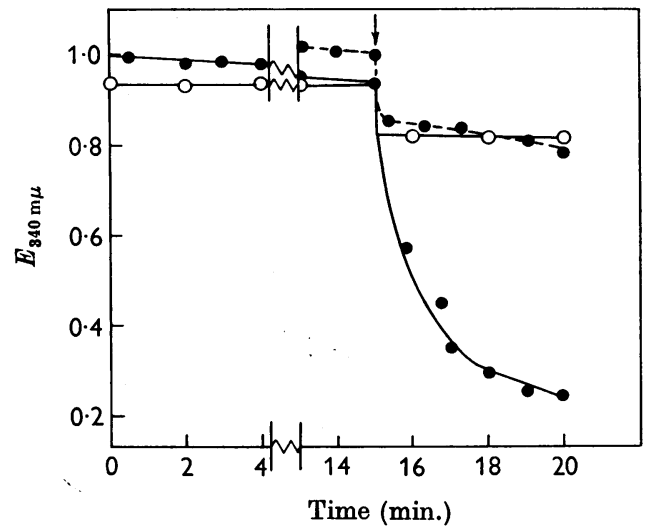

Fig. 5. $\beta$-Hydroxypropionate-dehydrogenase activity in unfractionated extracts. At zero time reaction mixtures contained: $0.5 \mu$ mole of NADH; $1.9 \mathrm{ml}$. of $0.015 \mathrm{M}$-phosphate buffer, pH 7.4; either extract (1.62 mg. of protein) (O) or an equivalent amount of boiled extract (O). At the time indicated by the arrow $8 \mu$ moles of malonic semialdehyde $(\longrightarrow)$ or $8 \mu$ moles of acetaldehyde $(---)$ were added. The final volume in each case was $3.0 \mathrm{ml}$. On the addition of both the substrates there is a decrease in extinction of about 0.11 owing to dilution of the mixture with either of the aldehyde solutions. The extinction at $340 \mathrm{~m} \mu$ was measured at room temperature against control cells lacking NADH only.
$\beta$-Hydroxypropionate dehydrogenase. No reduction of $\mathrm{NAD}^{+}$or $\mathrm{NADP}^{+}$could be demonstrated at $\mathrm{pH} 6 \cdot 0-9 \cdot 0$ on the addition of $\beta$-hydroxypropionate and cell-free extract by using the method of Den et al. (1959). However, the reduction of malonic semialdehyde by extracts in the presence of NADH to produce $\mathrm{NAD}^{+}$and $\beta$-hydroxypropionate could be readily shown (Fig. 5). Acetaldehyde, a decomposition product of the substrate, did not cause oxidation of NADH under the same assay conditions.

During the oxidation of $0.243 \mu \mathrm{mole}$ of NADH (reaction time, $25 \mathrm{~min}$.) the malonic semialdehyde in the reaction mixture decreased by $0.37 \mu$ mole; this lack of equivalence could be due to spontaneous decomposition of malonic semialdehyde during the experiment and to side reactions catalysed by the crude extract.

Malonic semialdehyde-decarboxylase system. $\mathrm{NAD}^{+}$ was reduced when malonic semialdehyde was incu-

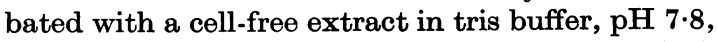
containing 2-mercaptoethanol, provided that CoA was added (Fig. $6 a$ ). Besides reduction of $\mathrm{NAD}^{+}$, carbon dioxide and a compound that readily gave a hydroxamate were produced.

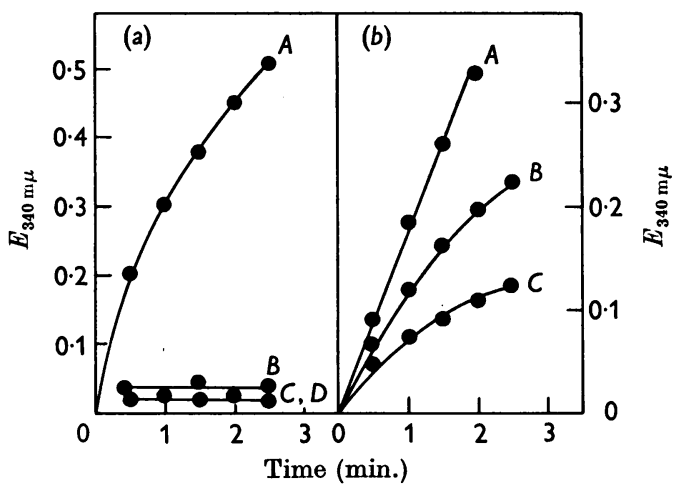

Fig. 6. (a) Malonic semialdehyde oxidative-decarboxylase activity in unfractionated extracts, and $(b)$ the effect of arsenite on this reaction. (a) The complete reaction mixture

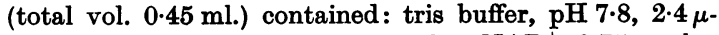
moles; 2-mercaptoethanol, $2 \cdot 5 \mu$ moles; $\mathrm{NAD}^{+}, 0 \cdot 75 \mu$ mole; CoA, $0.5 \mu$ mole; malonic semialdehyde, $0.5 \mu$ mole; extract, $0.19 \mathrm{mg}$. of protein. The reaction was started by the addition of malonic semialdehyde and followed at room temperature by measuring the extinction at $340 \mathrm{~m} \mu$ against a control lacking malonic semialdehyde only. $A$, Complete reaction mixture; $B$, no $\mathrm{CoA}$, otherwise identical with $A$; $C$, an equivalent amount of boiled extract was used instead of active enzyme; $D$, acetaldehyde $(0 \cdot 5 \mu \mathrm{mole})$ replaced the malonic semialdehyde and was used to start the reaction. The results of $C$ and $D$ were identical. (b) The complete reaction mixture was the same as in $(a)$ plus various amounts of arsenite. The reaction was started and followed as in $(a)$ but a different extract was used ( $0.38 \mathrm{mg}$. of protein). $A$, No arsenite; $B, 0.0225 \mu$ mole of arsenite; $C, 0.45 \mu$ mole of arsenite. 
The evolution of carbon dioxide was followed manometrically (gas phase: nitrogen plus carbon dioxide, 95:5) at $30^{\circ}$. Flasks containing $4 \mu$ moles of $\mathrm{NAD}^{+}, 3 \mu$ moles of $\mathrm{CoA}$ and $8 \mu$ moles of malonic semialdehyde in $0.042 \mathrm{M}$-bicarbonate buffer (total vol. $3 \mathrm{ml}$.) were set up. One $\mu$ mole of carbon dioxide was produced above the endogenous and control levels in $7.5 \mathrm{~min}$. on adding extract $(12 \mathrm{mg}$. of protein). The extract had been dialysed for $12 \mathrm{hr}$. against water containing traces of $\mathrm{NAD}^{+}$ and 2-mercaptoethanol. Hydroxamate assay of flask contents showed that, after $7.5 \mathrm{~min}$., $0.6 \mu$ mole of, presumably, acetyl-CoA was present. Control flasks, one without enzyme, one without CoA and one without $\mathrm{NAD}^{+}$, showed that the evolution of carbon dioxide was due to an enzyme reaction and that both $\mathrm{CoA}$ and $\mathrm{NAD}^{+}$were essential.

Arsenite inhibits a similar enzyme present in Pseudomonas fluorescens grown with acetylenemonocarboxylic acid (Yamada \& Jakoby, 1960). Arsenite inhibits this enzyme system also (Fig. 6b); $0.05 \mathrm{~mm}$-sodium arsenite causes about $47 \%$ inhibition.

Glyoxylate-cycle enzymes. The evidence from experiments with isotopes described above strongly suggests an active glyoxylate cycle (Kornberg \& Krebs, 1957) in propionate-grown cells.

When cell-free extracts, dialysed overnight against running tap water (to remove isocitratedehydrogenase activity), were incubated at $30^{\circ}$ with isocitrate, $\mathrm{Mg}^{2+}$ ions and GSH, an oxo acid was produced. Chromatography of its 2,4-dinitrophenylhydrazone and the absorption spectrum of this derivative in the range $380-600 \mathrm{~m} \mu$, when dissolved in equal volumes of $10 \%(\mathrm{w} / \mathrm{v})$ sodium carbonate and $1.5 \mathrm{~N}$-sodium hydroxide, showed it to be glyoxylic acid.

The specific activity of isocitrate lyase was $0.32 \mu$ mole of glyoxylate produced/mg. of protein/ $\mathrm{hr}$. Cells grown with glucose $(0.01 \mathrm{M})$ had no detectable isocitrate-lyase activity; the enzyme was formed when such cells were transferred to the propionate growth medium, its specific activity rising to the quoted value in $25 \mathrm{hr}$.

Malate synthase was also present, the enzyme being confined to the same fraction as that containing malate synthase in acetate-grown cells (Callely \& Lloyd, 1964). The specific activity was $3.0 \mu \mathrm{moles}$ of substrate used $/ \mathrm{mg}$. of protein $/ \mathrm{hr}$.

\section{DISCUSSION}

From the experiments with labelled propionate, plus the additional evidence from the arsenite inhibition experiments, it can be concluded that Prototheca zopfii converts propionate into acetylCoA via the malonic semialdehyde pathway (Scheme 1).
In this reaction sequence only $\beta$-hydroxypropionate and malonic semialdehyde are likely to be detected in the radioautography experiments, as the pool size of the other intermediates, all CoA derivatives, would be too small for their detection. However, malonic semialdehyde is unstable; for example, a loss of $10-20 \%$ of malonic semialdehyde in phosphate buffer, $\mathrm{pH} 6.0$, occurs in $24 \mathrm{hr}$. at $0^{\circ}$, and about $50 \%$ is lost in $24 \mathrm{hr}$. at room temperature (Professor M. J. Coon, personal communication). Hence any malonic semialdehyde present in reaction mixtures would not survive the treatment given to the methanol-soluble material before radioautographic analysis.

That only $\beta$-hydroxypropionate was detected when fortified extracts metabolized $\left[1{ }^{14} \mathrm{C}\right]$ propionate is thus consistent with the proposed pathway. Additional labelled compounds from $\left[2-{ }^{14} \mathrm{C}\right]$ propionate were shown to be tricarboxylic acidcycle intermediates or compounds directly derived therefrom, with the exception of X. Again this is expected, for C-2 of propionate should become the methyl carbon of the acetyl moiety of acetyl-CoA and thus be incorporated into tricarboxylic acidcycle intermediates, whereas C-1 of propionate is lost before acetyl-CoA is produced.

The changes in the percentage incorporation of label into citrate and malate from $\left[2-{ }^{14} \mathrm{C}\right]$ propionate in the presence and absence of glyoxylate or isocitrate suggest a functional glyoxylate cycle (Kornberg \& Krebs, 1957). That isocitrate lyase and malate synthase were present, and that their specific activities are similar to the values found in extracts of acetate-grown cells (Callely \& Lloyd, 1964), support this idea. Thus the tricarboxylic acid

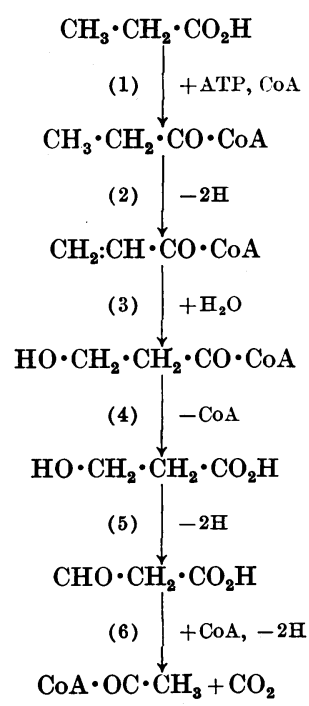

Scheme 1. The malonic semialdehyde pathway. 
cycle and its ancillary glyoxylate cycle would form the metabolic basis by which $P$. zopfii would grow on, as opposed to merely oxidize, propionate.

Compound $\mathrm{X}$ is still a mystery. It was not detected when $\left[2-{ }^{14} \mathrm{C}\right]$ acetate was used instead of $\left[2-{ }^{14} \mathrm{C}\right]$ propionate. The possibility that $\mathrm{X}$ might be $\beta$-alanine, produced by amination of acrylyl-CoA or a transamination involving malonic semialdehyde, was ruled out by co-chromatography experiments and also because $\mathrm{X}$ is not produced from $\left[1{ }^{14} \mathrm{C}\right]$ propionate.

The accumulation of $\alpha$-oxoglutaric acid when whole cells oxidizing propionate were poisoned with arsenite was expected. The accumulation of malonic semialdehyde was clarified by finding that arsenite inhibited the malonic semialdehydedecarboxylation system (reaction 6) in cell-free extracts.

The demonstration of all the enzymes involved provides additional confirmation for this pathway. Though there is as yet no direct evidence for the hydration of acrylyl-CoA, the occurrence of reactions (3) and (4) is evidenced by the facts that extracts metabolize acrylyl-CoA and $\beta$-hydroxypropionyl-CoA, that a deacylation occurs and that $\beta$-hydroxypropionate is detected in radiotracer studies. Inability to obtain the theoretical stoicheiometry in the deacylation experiments could be due to the use of acetylhydroxamate as an arbitrary standard, as different hydoxamates give different colour values in the ferric chloride assay.

Though $\beta$-hydroxypropionate dehydrogenase can be assayed in either direction (Coon \& Robinson 1962), in this case only the reverse reaction could be shown. If the Prototheca enzyme has similar characteristics to that in pig kidney (an equilibrium constant of $9 \times 10^{-12}$ and a Michaelis constant of $22 \mathrm{~mm}$ for $\beta$-hydroxypropionate with $\mathrm{NAD}^{+}$at $1 \mathrm{~mm}$; Coon \& Robinson, 1962), then it would be expected that the back reaction would be easier to demonstrate. These values would also indicate that the pool size of $\beta$-hydroxypropionate could be appreciable; the ease with which this compound can be detected in tracer experiments bears this out.

The pathway is rather wasteful of carbon unless that lost by the decarboxylation of malonic semialdehyde can be assimilated. If this is the only way Prototheca metabolizes propionate, then the problems it faces when grown with propionate are the same as those when grown with acetate. Thus the metabolism of propionate-grown cells should be identical with that of acetate-grown cells, with the addition of, if it is an induced pathway, the reactions given in Scheme 1. The present results and those of Callely \& Lloyd (1964) illustrate this.

The flagellate protozoan, Ochromonas malhamensis, which requires vitamin $\mathrm{B}_{12}$ for growth, metabolizes propionate via the succinate pathway, in which the methylmalonyl-CoA to succinyl-CoA step is catalysed by an enzyme that has the coenzyme form of vitamin $B_{12}$ as a cofactor (Arnstein \& White, 1962). As Prototheca zopfii has no nutritional need for vitamin $B_{12}$ and metabolizes propionate by a vitamin $B_{12}$-independent route, it may be that unicellular algae with the same nutritional requirements as Prototheca will metabolize propionate by a vitamin $B_{12}$-independent pathway, if not by the same pathway as $P$. zopfii. Whether this organism can synthesize vitamin $\mathrm{B}_{12}$ and use the coenzyme form of this vitamin in pathways which in some organisms are known to be vitamin $B_{12}$-dependent remains to be seen.

\section{SUMMARY}

1. Propionate oxidation by washed whole cells of Prototheca zopfii is inhibited by arsenite with accumulation of $\alpha$-oxoglutaric acid and malonic semialdehyde.

2. When fortified cell extracts metabolize $\left[1-{ }^{14} \mathrm{C}\right]$ propionate only one radioactive compound, $\beta$-hydroxypropionate, can be detected. In similar experiments with $\left[2{ }^{14} \mathrm{C}\right]$ propionate, however, $\beta$ hydroxypropionate, aspartate, glutamate, citrate, malate and an unidentified compound were all labelled.

3. The addition of unlabelled glyoxylate or isocitrate to fortified extracts metabolizing $\left[2-{ }^{14} \mathrm{C}\right]$ propionate increased the proportion of label incorporated into malate. Isocitrate lyase and malate synthase were found in extracts of propionategrown cells.

4. Experiments with cell-free extracts showed that the reactions of the malonic semialdehyde pathway could account for the conversion of propionate into acetyl-CoA. The malonic semialdehyde oxidative-decarboxylation system is inhibited by arsenite.

The authors are especially indebted to Professor M. J. Coon for his advice on the properties of malonic semialdehyde, the gift of the ester acetal of this compound and details on the preparation of $\beta$-hydroxypropionate. They also thank Dr J. R. Quayle and Dr P. J. Large for assisting in the malate-synthase assays, and $\mathrm{Mr} \mathrm{H}$. Swain, of this Department, for making the French press. D.L. is indebted to the Department of Scientific and Industrial Research for a Studentship.

\section{REFERENCES}

Anderson, E. H. (1945). J. gen. Physiol. 28, 287.

Arnstein, H. R. V. \& White, A. M. (1962). Biochem. J. 83, 264.

Barker, H. A. (1935). J. cell. comp. Physiol. 7, 73.

Beck, W. S. \& Ochoa, S. (1958). J. biol. Chem. 232, 931. Callely, A. G. \& Lloyd, D. (1964). Biochem. J. 90, 483. 
Coon, M. J. \& Robinson, W. G. (1962). In Methods in Enzymology, vol. 5, p. 457. Ed. by Colowick, S. P. \& Kaplan, N. O. New York: Academic Press Inc.

Den, H., Robinson, W. G. \& Coon, M. J. (1959). J. biol. Chem. 234, 1666.

Deutsch, D. H. \& Phillips, R. E. (1957). In Methods in Enzymology, vol. 3, p. 421. Ed. by Colowick, S. P. \& Kaplan, N. O. New York: Academic Press Inc.

Dixon, G. H. \& Kornberg, H. L. (1959). Biochem. J. 72, 3 P.

Flavin, M., Castro-Mendoza, H. \& Beck, W. S. (1956a). Fed. Proc. 15, 252.

Flavin, M., Castro-Mendoza, H. \& Ochoa, S. (1956b). Biochim. biophys. Acta, 20, 591.

Flavin, M., Ortiz, P. J. \& Ochoa, S. (1955). Nature, Lond., 176, 823.

Friedberg, F., Adler, J. \& Lardy, H. A. (1956). J. biol. Chem. 219, 943.

Friedemann, T. E. \& Haugen, G. E. (1943). J. biol. Chem. $147,415$.

Giovanelli, J. \& Stumpf, P. K. (1958). J. biol. Chem. 231, 411.

Grunert, R. R. \& Phillips, P. H. (1951). Arch. Biochem. 30, 217.

Gurnani, S., Mistry, S. P. \& Johnson, B. C. (1960). Biochim. biophys. Acta, 38, 187.

Jones, M. E. \& Lipmann, F. (1955). In Methods in Enzymology, vol. 1, p. 585. Ed. by Colowick, S. P. \& Kaplan, N. O. New York: Academic Press Inc.

Kalnitsky, G. \& Tapley, D. F. (1958). Biochem. J. 70, 28.

Katz, J. \& Chaikoff, I. L. (1955). J. Amer. chem. Soc. 77, 2659.

Kornberg, H. L. (1958). Biochem. J. 68, 535.
Kornberg, H. L. \& Krebs, H. A. (1957). Nature, Lond., $179,988$.

Lardy, H. A. \& Adler, J. (1956). J. biol. Chem. 219, 933.

Lardy, H. A. \& Peanasky, R. J. (1953). Physiol. Rev. 33, 560.

Lengyel, P., Mazumder, R. \& Ochoa, S. (1960). Proc. nat. Acad. Sci., Wash., 46, 1312.

Lipmann, F. \& Tuttle, L. C. (1945). J. biol. Chem. 159, 21.

Mahler, H. R. \& Huennekens, F. M. (1953). Biochim. biophys. Acta, 11, 575.

Radin, N. S., Metzler, D. E., Bloom, R. J. \& Westerfield, W. W. (1955). Biochem. Prep. 4, 60.

Reeves, H. C. \& Ajl, S. J. (1963). Biochem. biophys. Res. Commun. 12, 132.

Rendina, G. \& Coon, M. J. (1957). J. biol. Chem. 225, 523.

Robinson, W. G. \& Coon, M. J. (1963). In Methods in Enzymology, vol. 6, p. 549. Ed by Colowick, S. P. \& Kaplan, N. O. New York: Academic Press Inc.

Stadtman, E. R. (1955). J. Amer. chem. Soc. 77, 5765.

Stadtman, E. R. (1957). In Methods in Enzymology, vol. 3, p. 931. Ed. by Colowick, S. P. \& Kaplan, N. O. New York: Academic Press Inc.

Stadtman, E. R., Overath, P., Eggerer, H. \& Lynen, F. (1960). Biochem. biophys. Res. Commun. 2, 1.

Swim, H. E. \& Krampitz, L. O. (1954). J. Bact. 67, 419.

Umbreit, W. W., Burris, R. H. \& Stauffer, J. F. (1957). Manometric Techniques, p. 1. Minneapolis: Burgess Publishing Co.

Vagelos, P. R. (1960). J. biol. Chem. 235, 346.

Warburg, O. \& Christian, W. (1941). Biochem. Z. 310, 384.

Yamada, E. W. \& Jakoby, W. B. (1960). J. biol. Chem. 235, 589 .

\title{
Maleic Acid-Induced Inhibition of Amino Acid Transport in Rat Kidney
}

\author{
By LEON E. ROSENBERG \\ The Metabolism Service, National Cancer Institute \\ AND STANTON SEGAL \\ Clinical Endocrinology Branch, National Institute of Arthritis and Metabolic Diseases, \\ National Institutes of Health, Bethesda 14, Md., U.S.A.
}

(Received 31 October 1963)

Maleic acid, the cis isomer of fumaric acid, has long been known to be a potent inhibitor of several enzyme systems in vitro (Morgan \& Friedmann, $1938 b$ ), but its effects in vivo have been investigated only recently. Berliner, Kennedy \& Hilton (1950) reported that acidotic dogs, given maleic acid intravenously, failed to acidify their urine. These authors also noted a consistent increase in urinary sodium, phosphorus and bicarbonate as well as a decrease in the maximal concentration of glucose able to be reabsorbed by the kidneys ( $T_{m}$ glucose) in these poisoned animals. Harrison \& Harrison
(1954) found that the administration of maleic acid to rachitic rats resulted in aminoaciduria, glycosuria and phosphaturia, and commented on the similarity of these findings to those in human subjects exhibiting 'the Fanconi syndrome'. Angielksi, Niemiro, Makarewicz \& Rogulski (1958), Angielski \& Rogulski (1959) and Angielski, Rogulski \& Madonska (1960) corroborated these findings in rats, documented the time-course of maleate poisoning and noted its effect on free thiol groups in kidney parenchyma. These workers also compared the effects of the administration of 